$$
\text { DOE/PC/ } 89908-722
$$

DOE/PC/89908--T22

D1292 040661

QUARTERLY' TECHAYCAL PROGRESS REPORT HO. 11

APRIL - JUWE 1992

EMGINEERING DESIEN NMD AMALYSIS OF ADVANCED PHYSICAL

FINE COAL CLEANING TECHWOLOGIES

for

U.S. DEPARTMENT OF ERERGY

PITTSBURGH ENERGY TECHOLOGY CENTER

PITTSBURGH, PA

CONTRACT KN. DE-AC22-89PC89908

\title{
SUBMITTED BY
}

P.M. GALLIER

PROJECT MAMAGER

ASPEN TECHNOLOGY, IMC.

25I VASSAR STREET

CAMBRIDGE, 02139

DISTRIBUTION OF THIS DOCUMENT IS UNHIMTTEO

JULY 20, 1992

Hin:

SEP 081992 


\section{TABLE OF CONTENTS}

Page

1.0 INTRODUCTION 1

2.0 ADMINISTRATIVE ITEMS 2

3.0 TASK 1.2 - Engineering Analys is of Conventional 3

3.1 Planned Scope of Work 3

3.2 Technical Status 3

3.2.1 Updates, and Testing of Task 2 Models 3

3.2.2 Rdditional Task 2 Model Discussions 8

3. (3.3 ASPEN PLUS Implemertations 9

3.2.4 Task 2 Topical Reports 11

3.2.5 Task 2 Model Valfdation Reports II

4.0 TASK 1.3 - Engineering Analysis of Unit Operations 12 for Processing Fine and Uitrafine Coals

TASK 1.4 - Enginearing Anaiysis of Advanced Tecinnologies 12 for Physical Cleaning of $5 i$ ine and Ultrafine coals

4.1 Planned Scope of Work 12

4.2 Tecinical Status 12

5.0 TASK 1.6 -Laboratory Testing 13

5.1 Planned Scope of Mork 13

5.2 Technical Status 13

5.2.1 Froth Flotation 13

5.2.2 Other Advanced Processes 14

6.0 QUARTER HO. 12 WORK PLAN 18

Aspen Technology, Itce. / 7-20-92 / DE-AC22-89pC89908

Enginearing Design and Analys is of Advenced Physical Fine Cool Cleaning Technologies 


\title{
1.0 INTRODUCTION
}

This project is sponsored by the United States Departaent of Energy (DOE) for the "Engineering Design and Analysis of Advanced Phystcal Fin Coal Cleaning Technologies:. The major goal is to provide the stmulation tools for modeling both conventional and advanced coal cleaning technologies. This DoF project is part of a major research initiative by the Pittsburgh Energy Technology Center (PETC) almed at advancing three advanced coal cleaning technologies - heavy-l iquid cylconing, selective agglomeration, and advanced goth flotation through the proof-of-concept (POC) level.

The commercially avallable ASPEM PLUS process simulation package will be extended to handle coal cleaning applications. Algorithms for predicting the process performance, equipment size, and flowsheet economirs of comercial coal cleaning devices and related ancillary equipment will be incorporated into the coal cleaning simulator.

This report is submitted to document the progress of Aspen Technology. Inc. (Aspentoch), its contractor, ICF Kaiser Engineers, Inc., (ICF KE) and CQ Inc." a subcontractor to ICF KE, for the perfod of March through June 1992. ICF KE is providing coal preparation consulting and processing ongineering services in this work and they are responsible for recomending the destgn of models to represent conventional coal cleaning equipment and costing of these models.

\section{DLSCLAIMER}

\begin{abstract}
This report was prepared as an account of Work sponsored by an agency of the United States Government. Neither the United States Government nor any agency thereof, nor any of tieir employes, makes any warranty, express or implied, or assumes any legal liability or responsibility for the accuracy, completeness, or usefulness of any information, apparatus, product, or process disclosed, or represents that its usc would not infringe privately ownod rights. Reference berein to any specific commercial product, process, or service by trade name, trademark, manufacturer, or otherwise does not necessarily constitute or imply its endorsement, recommendation, or favoring by the United States Government or any agency thr eef. The views and opinions of authors expressed herein do not necessarily state of reflect thowe of the United States Governmeat of any agency thereof.
\end{abstract}




\subsection{ADMIHISTRATIVE ITENS}

Aspentech, and CQ Inc attended a kfckoff moting for Task 6 on April 2, 1992 at Penn State University. The discussion focused on froth flotation modeling and the Task 6 experimental program. The participants at that eeting also included representatives frow DOE, DOE project consultants, and members of the Penn state Project toan.

A project review moeting was held at DOE PETC on May 19, 1992. The goals for this meeting were to follow up on the froth flotation discussion begun at the Task 6 kickoff meeting, and to discuss model validation.

An internal project team meting was held between AspenTech, ICF KE, and CQ Inc. on June 30 1992. The discussion focused on manpower assigninents and schaduling for the remainder of the project. The project team agread to hold weekly conference call wetings on Friday afternoon until the complet ion of the project. 
3.0 TASX 1.2 - EMAIMEERIM AMLIYSIS OF CONVENTIONAL COARSE COAL CLEANIMG

\subsection{Planned Scope of Mork}

The work plan for the perfod called for the completion of all Task 2 items including wodel documentation, testing, and validation.

\subsection{Technical Status}

The technical status of 11 Task 2 1tens are discussed below in the following sectlons.

\subsubsection{Updates, and Testing of Task 2 Models}

\section{Screens and Centrifuges}

Hodel validation procedures were discussed at a meeting between the project team and DOE-PETC on May 19, 1992. It became apparent at the meeting that one of the problems occurring was the inability of some of the screen models to give a cont inuous relationship between tons per hour oversize and screen cut size. In the original desilime screen model, the input to the model was both separation size and screen efficiency. The fficiency value was used in the calculation to place 100 minus the efficiency value as a fractional recovery for all size intervals less than the screen stze into the screen oversize. These calculations reveal that step functions occur in tons per hour oversize flow. When the screen opening is varied. Another algorithm was developed during the work period to allow a continuous function to resuit from the desilme screen model when performing sensitivity betweon screen optning. The model was developed from several sets of data collected from desilime screening operations at $0.5 \mathrm{~m}$ size. Primarlily, the sharpness index was calculated for subsequent use in the model. Then, the logistic equation was used to create a set of fractional recovery values from the $d 50$ and sharpness indox parameters. The resulting calculations give a wore realistic separation of the screen feed as compared to the old algorithm. If the user of the model wishes to use this approach, he should enter the $d 50$ value and an efficiency value of 0 . If an efficiency value greater than zero is entered, the calculations will follow the path of the old algorithm. The doubledeck deslime screen was also updated to include this algorfthm. A similar approach is utilized in the inclined screen models (wet. double-deck wet, dry, and double-deck dry inclined screens).

Both screen and centrifuge models rely on the calculation of average particle size to predict the moisture content of the screen oversize and centrifuge discharge products (cake). Hhen selectivity curve approach is used to calculate screen performance, reasonable values for moisture can be obtained by setting the dewatered product film thickness to value of approximately $0.008 \mathrm{~mm}$. In the screen 
algorithas, where efficiency is an input parameter by the user, the wodel uses the efficiency to deterwine the recovery of all size fractions finer than the separation size. If the effictency is 80 percent, then the recovery of the fines to the oversize stream is 20 percent. This approach recovers a considerable amount of fines to the oversize, resulting in erroneously high values for predicted product oisture content. In order to be able to wake both approaches to modeling screens compatible with the algarith to prodict oisture content of the screen oversize, further modifications will need to be made to the scrnen algorithm. The preferred changes were discussed with Aspentech at the weeting on June 30, 1992, and will be discussed in the monthly progress report for July 1992. When the screen algorlthins have been finalized, the centrifuges w\$11 be tested again and final model paraneters adjusted to result in molsture contents comparable to centrifuge manufacturer data.

\section{Gravity-based Devices}

As part of additional testing for the gravity-based device models (primarily haavy-media cyclones, concentration tables, and wateronly cyclones), data from three coal cleanablitty characterization test programs conducted at the Coal quality Dovelopment Center are being used to compare calculated versus actual prohable error and specific gravity of separation by particl size. These three test programs used these three devices in various combinations, giving a total of fourteen different flowsheets to test. These flowsheets have been set up as ASPEN PLUS input flles. Comparisons between model results and actual operating results will be avaflable in July. The flowsheets are conffgured for Kentucky No. 11, Illinois No. 6, and the Stockton-Lewiston Coal seans. A Hide range of separating gravities and particle sizes will be covered in this testing.

\section{Roll Crusher}

The roll crusher model was tested using EPRI Coal Quality Information Systean (CQ15 ${ }^{\text {TM }}$ ) washabllity data for two coais (Meigs Creek and Mary Lee Seams). These tests compared actual crushed 5 ize distributions to those predicted by the roll crusher model. It was found that the model uses the 20 percent retained size as the definition of topsize of the crusher product. If $3 / 4 \mathrm{in}$. product topsize is required and the user inputs $3 / 4 \mathrm{in}$. size for the crusher gap setting, the odel gives product ize distribution with about 20 percent retained on $3 / 4$ in. size. For example, flgure 1 shows the actual size distribution for the Mary Lee seam coal crusined to 95 percent passing $3 / 4$ in. This gives a 20 percent retained size value of slightly greater than $3 / 8 \mathrm{in.}$ (approximateiy $11.2 \mathrm{~m}$ ). When SET 11.1m (SET is the parametep for crusher gap size), the resuiting size distribution approximates thet of the actual CQIS crushed to $3 / 4 \mathrm{in}$. coal sample. When $3 / 4 \mathrm{in}$. (19.05m) is used for 
SET the distribution is wuch coarser, resulting in a 20 percent retained size of about $3 / 4$ in.

Roll crushers are typically used to minimize the amount of fines generated by crushing. The model appears to do this as wall, but tends to underestiwate the anount of fines, giving values silghtly greater than the feed sample for the finest sizes. This is illustrated in Figure 2. White the model gives progressively finer size distributions with decreasing values of SET for the Mary Lee sean coal in the coarser size ranges, the size distribution in the fine size range tends to merge. This is in contrast to the size distributions given for the varfous crushed products as shown in Figure 3.

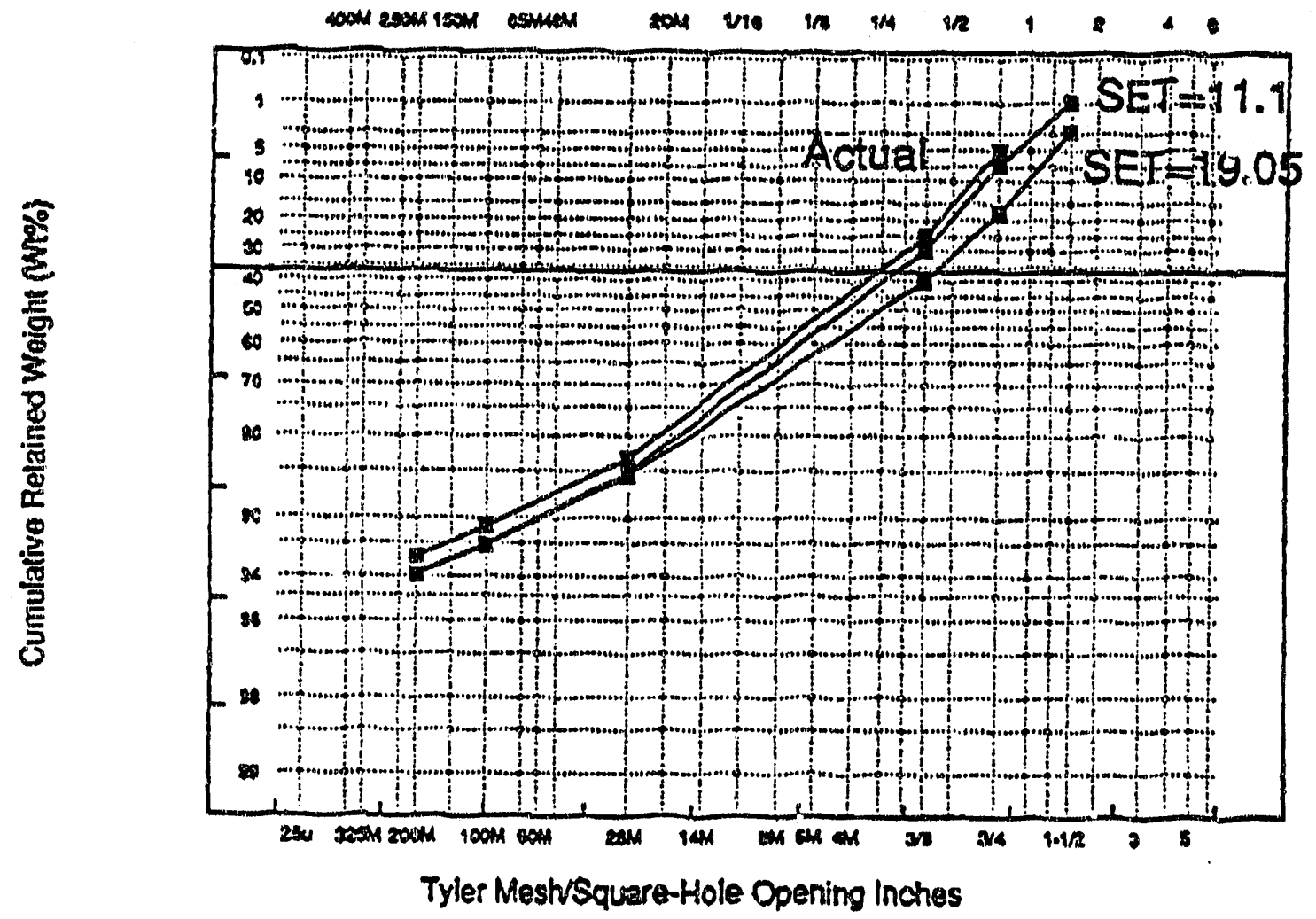

Figure 1. Mary Lee Sean Crushed to 3/4' Topsize lodel vs Sample Comparison 


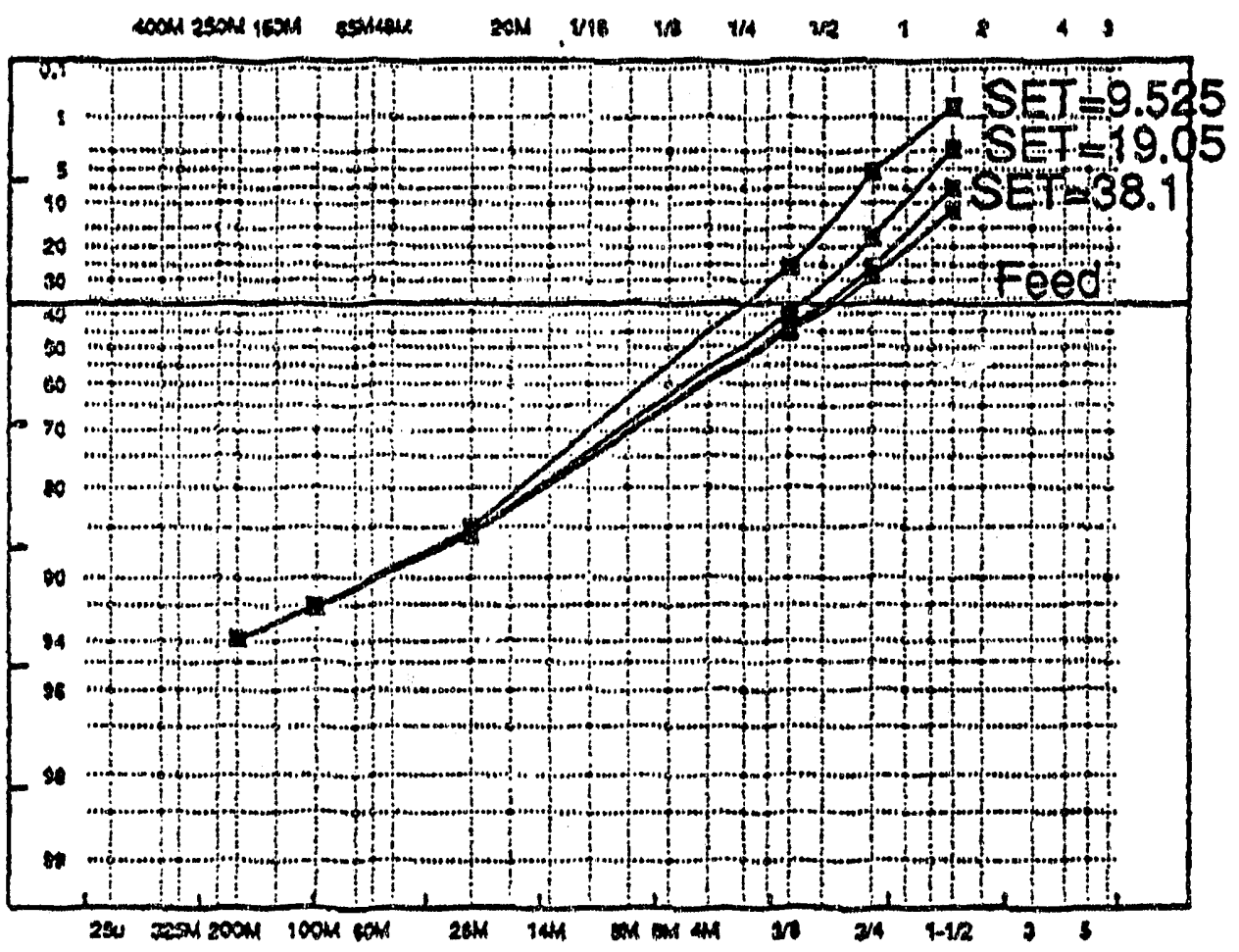

Tyler MesthSquara.Hole Copening Inches

Figure 2. Crusher Model Results for Mary Lee Sean Cosi 


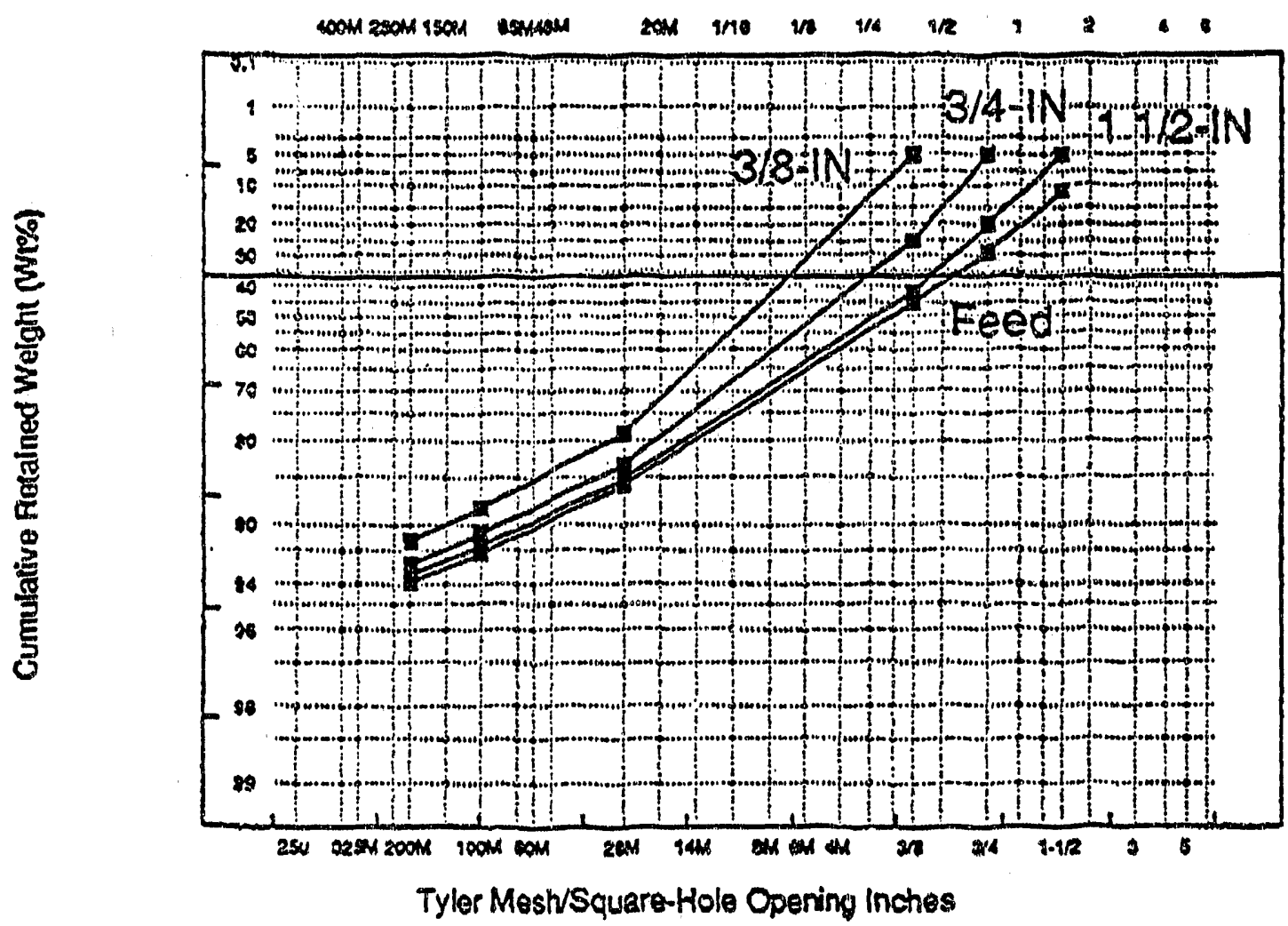

Figure 3. CQIS Crushed Coal Size Distributions for Mary Lea Saan Coal 


\subsubsection{Additional Task 2 Model Discussions}

\section{Froth Flotation}

Several items regarding the conventional froth flotation model were discussed at project reviow meeting at DOE PETC on May 19, 1992. These included:

- Determining how to get data in time to neot the overall project schedule.

- Proposing a simplified model to be dellvered if data is not recelved in time.

- Calibrating the model for coal rank with only three coals represented.

- Addressing batch to continuous scale-up.

A review of work already completed to generate the equations for the rank/reagent correlations that are in the present model was presented. The data used in these correlations were froin nine coal cleanability characterizations conducted at the coal quality Development Center covering a range in coal ranks froin high volatile $B$ bituminous to low volatile bituminous. Good correlations between recovery and rank (percent carbon on dry wineral matter free basis) and reagents were found. These correlations can be found in the froth flotation topical report draft.

Concern exists for completing all models and documentation in time for inclusion in the final package. A simplifted model was proposed to take the place of the kinetics wodel should time be a consideration. This odel would be based on partition curves (separating gravity and protable error) generated by the Task 6 test program.

A review of the rate and residence time distributions in froth flotation scale-up was presented. In testing various combinations of two residence time equations and two rate equations, it was found that the froth factor documented by WENCO is the most important variable in scaling from batch to continuous flotation. This factor accounts for differences in pulp level and froth removal rate between laboratory and plant froth flotation cells.

In plant surveys, MEMCO found the ratio of batch rate constant to plant rate constant to vary as the percent of froth height over the ifp of the cell in the plant (froth factor) varied. When a high pulp Invel of high froth factor was maintained in the plant, the ratio vetween laboratory and plant kinetics decreased. Most laboratory tests were run with a high pulp level. During this analysis, the froth factor was applied successfully to results from two test programs conducted by Arnold (Ph.D. Thesis, 1989). These results will be documented in the final froth flotation topical report. 
From this analysis, it was proposed that a perfect-mixers-in-series equation bo used with the classical first-order rate equation modified for froth factor for scale-up from batch to continuous.

\section{Rotary Breaker}

The rotary breaker model currently in the DOE Coal preparation Simulator developed by Austin, Luckie, and KIIma of Penn State University still represents the most advanced modeling effort of this unit operation. As such, this model is currently being incorporated into an ASPEN PLUS system model and should be avaflable for use in July.

ICF KE is investigating several alternatfves to make the model more accurate and understandable to the user.

\subsubsection{ASPEN PLUS Implementations}

The changes made to the Coal Cleaning simulator during this period were mostly almed at correcting problews found during the flowsheet validations. One modification was made to the washability interpolation. Prior to interpolation, the feed size distribution is preprocessed by a subroutine which resets the size intervals. That subroutine was changed to ensure that standard screen sizes be used for the size intervals, with only the topsize being the actual user specified size 1imit. This should prevent problems such as the size range being much wider than that provided by the user (previousiy, this subroutine would add fine size intervals to the input size range, in some cases).

Another change made was the modification of the heavy media cyclone water balance algorfthm. Because of the internal calculations of both the amount of media and makeup water required, the water balance was not being made correctly in the case where feed that was too dilute. The report writer for this model was also modified in order to correctly label the material balances reported.

Other changes made were the addition of fifteen coals to the Coal Property Databank (Table 3), and the referencing of ut 11 it les in the screen cost models for operating cost calculations.

Finaliy, number of problems had been roported for cCS cost models. These were related to discrepancies between uos block sizing calculations and cost block sizing calculations, and utilities (horsepower requirement) calculations. The corrections were applied to the latest CCS version.

Changes were also made to the CCS documentation. The documentation format is being totally revised to provide more model descriptions and better compatibility with the hodelWanager interface. 
Tabio 3. Cosls in Coal Proporty Databank

\begin{tabular}{|c|c|c|}
\hline Coal Mame & Databank Nams & Coal Rank \\
\hline Illinots No. 6 & ILLINOIS-MO-6 & $\begin{array}{l}\text { High volatile B } \\
\text { bituminous }\end{array}$ \\
\hline Meigs Creek & MEIGS "CREEK & $\begin{array}{l}\text { High voiatile } \\
\text { bituminous }\end{array}$ \\
\hline Pittsburgh & PITTSBUKEH & $\begin{array}{l}\text { High volatile A } \\
\text { bituninous }\end{array}$ \\
\hline Indiana No. 5 & INDIANA-NO-5 & $\begin{array}{l}\text { High volatile } \mathrm{C} \\
\text { bituminous }\end{array}$ \\
\hline Kentucky No. 9 & KENTUCKY-NO-9 & $\begin{array}{l}\text { High volatile B } \\
\text { bituminous }\end{array}$ \\
\hline Kentucky No. 11 & KENTUCKY-NO-11 & $\begin{array}{l}\text { High volatile C } \\
\text { bituminous }\end{array}$ \\
\hline Robinson & ROBINSON & Subbituminous C \\
\hline Anthracite Culm & ANTHRACITE-CULN & Semi anthracite \\
\hline $\begin{array}{l}\text { Lower Freeport }(50 \%) \text {, Upper } \\
\text { Freeport }(50 \%)\end{array}$ & LFREE50-UFREE50 & $\begin{array}{l}\text { High volat ile } \\
\text { bituminous }\end{array}$ \\
\hline Upper Freeport & UPPER-FREEPORT & $\begin{array}{l}\text { High volatile } \\
\text { bituminous }\end{array}$ \\
\hline $\begin{array}{l}\text { Upper Freeport }(20 \%) \text {, Lower } \\
\text { Kittanning }(80 \%)\end{array}$ & UFREE2O-UFREE80 & $\begin{array}{l}\text { Madium volatile } \\
\text { bituminous }\end{array}$ \\
\hline Upper Kittanning & UPPER-KITTANHING & $\begin{array}{l}\text { High volatile A } \\
\text { bituminous }\end{array}$ \\
\hline Lower Kittanning & LOWER-KITTAMNING & $\begin{array}{l}\text { Low volat11e } \\
\text { bituminous }\end{array}$ \\
\hline $\begin{array}{l}\text { Wilcox Group, Upper calvert } \\
\text { Bluff formation }\end{array}$ & HILCOX-UCALVERT & Lianite \\
\hline stockton-Lewiston & STOCKTOW-LEWISTON & $\begin{array}{l}\text { High volatile B } \\
\text { bituminous }\end{array}$ \\
\hline
\end{tabular}




\subsubsection{Task 2 Topical Roports}

Aspentech reviewed an updeted gravity model topical report during the work perfod. Thts report will be forwarded to DOE and DOE project consultants. The clessification topical report completion is being delayed to allow the incorporation of algorithm changes new being mide to the screen models.

\subsubsection{Task 2 Model Validation Reports}

Comments on all six flowshat velldetion roports were received during the work perlod. After moeting on May 10, 1982, with DOE PETC and their consultants, It was concluded that the AspenTech tean shov'd considar iternate appronches en the sodei valldation process. One suggested altermattve is to consider the use of equipment manufacturers as an independent source for individual model validation. Aspentech agreed to explore the alternatives and submit their findings to DOE at a later date. 
4.0 TASK 1.3 - Enginesing Analys is of Unit Operations for Processing Fine and Uitrafine coals

TASF. 1.4 - Engineering Analysis of Adyanced Thehtologies for Physical cleaning of Fine and Uitrafine Coals

\subsection{Planned Scope of Mork}

Progress was to be made in Tasks 3 , and 4.

\subsection{Technical Status}

A fine sizing sereen and wat ball will wodel will be the first wodels delivered in Task 1.3. The fine sizing screen model will be the formulation developed by hogers and Brame of Kennedy Van Saun Corporation for slzing fine coal at various pulp densities on inelined high-frequency 'jibrating sereens (Doprick type). The wet bull will will use a population balance approsch sypical of those developed at the University of Uiah and Penn State University.

The column flotation model developed at the Virginia Polytochnic Institute and State University (VPI) will be used as the model for advanced froth flotation in the ASPEN PLUS simulator. Relationships between probability of adhesion and various rank, size/specific gravity, ald ragent factors still noed to be determined.

The advanced cycloning model wfll be developed from data collected from DOE PETC's micro-Plag process development program. Relationships between particle size and relative separating density and probuble orror will be regressed from the avallable data. A functional form will be utillized to generate separation curves for individual size fractions, sinflar to the approach utflized for the conventional gravity separation models.

To date, no acceptable formilation has been found for modeling selective agglomeration. 


\subsection{TASK 1.6 - Laboratory Testing}

\subsection{Plannod Scope of Work}

The preliminary froth flotation tests were scheduled to begin. Feed sample characterizations were to be performed for Upper Freeport and Pittsburgh seam coals. The necessary data reduction was to begin.

\subsection{Technical Status}

\subsubsection{Froth Flotation}

The Upper Freeport sean froth flotation feed samples have been characterfzed by size and specific gravity. Preliminary froth flotation tests investigating frother and collector dosag and percent solids have been conducted for the crushed to 28 mesh topsize Upper Freeport sean coal. For these tests, three reagent conditions giving results over a range of flotation rate and recovery have been selected as the conditions for complete size and gravity anaiyses. These conditions are

Tost $10.16 \mathrm{Ib} / \mathrm{T}$ MIBC

Test \& $0.651 \mathrm{~b} / \mathrm{T}$ MIRC

Test $10.65 \mathrm{lb} / \mathrm{T} \mathrm{MIBC} \quad 0.65 \mathrm{lb} / \mathrm{T}$ Dodecane

For these tests, the feed sample is at 10 percent solids. Kinetic parameters, rate constant and ultimate recovery, were calculated for total yield for each test. For these tasts, uitimate recovery values for the yteld of the total coal sample ranged from $7_{2}$ to 82 percent. Values for the rate constant $k$ more than tripled.

Eight different rate equations are being evaluated for use in the final model. These equations are

- Classical first-order

- First-order with rectangular distribution of flotabllities

- fully-mixed reactor (exponential distribution of flotablitities)

- Arbiter second-order equation

- KI impel second-order equation

- First-order with sine wave

- Classical first-order with tim lag (Agar)

- Masural Ia equation (Lai)

As additional rate data is obtainad for the Upper Freeport and Pittsburgh sean coais, each set of data will be fitted to the equations listed above. Comparisons between actual recovery and ultimate recovery will be made for each equation. The equation with 
the best over 11 estimates of ultiwate recovery and the lowest. standard errors will be selected for use in the final model. All data obtained through August 1992 will be used in the final model equation selection. This data will cover all size and spectfic gravity fractions to be tested.

Kinetic parameters were calculated for the total yield and the yieid of plus and winus 400 mesh fractions for each of the prelininary tests. Som of these results are plotted in the attached graphs, using values calculatod for the classical first-order equation. Wille the exact numeric values for the rate constants and ultimate recovery are different for the other equations, the same trends are observed overall. Figure shows the variation of the rate constant with increasing collector (dodecane) dosage, and Fi jure 5. shows the variation of uitimate recovery. These tests were conducted at 10 percent solids and with $100 \mathrm{pl}(0.65 \mathrm{lb} / \mathrm{T}) \mathrm{MIBC}$. Note that the fine fraction floats at a lower rate than the coarse fraction, but to an overall higher recovery. As expected, flotation rate increases with increasing collector dosage. Ultimate recovery remains about constant as all of these tests give high overall recoveries. Figures 6 and 7 illustrate simflar patterns for increasing frother desage. No collector was added to these tests anc the solids content was 10 percent by weight.

The results in Figures 8 and 9 fo; increasing percent solids show quite interesting trends. The rate constants decrease with increasing solids content for the coarse fraction, while showing a minimum at 10 percent solids for the fines. Ultimate recovery, on the other hand increases with increasing percent solids for the cosise fraction while going through aximu it 10 percent sulids for the fines. These tests were conducted with $100 \mu 1$ MIBC; the concentration in the slurry was the same but the dosage on $1 \mathrm{~b} / \mathrm{T}$ basis decreased with increasing percent solids.

A sample of Pittsburgh seam coal has also been obtained for testing. Feed sample characterization and prelifinary froth flotation testing has begun.

\subsubsection{Other Advanced Processes}

A request for proposal for modeling liberation under Task 6 was prepared and subaitted to Penn State University. A proposal was obtained from PSU in response. Approval of the liberation work as a subcontract to Penn State University was requested to DOE. PETC'S contracting office. 


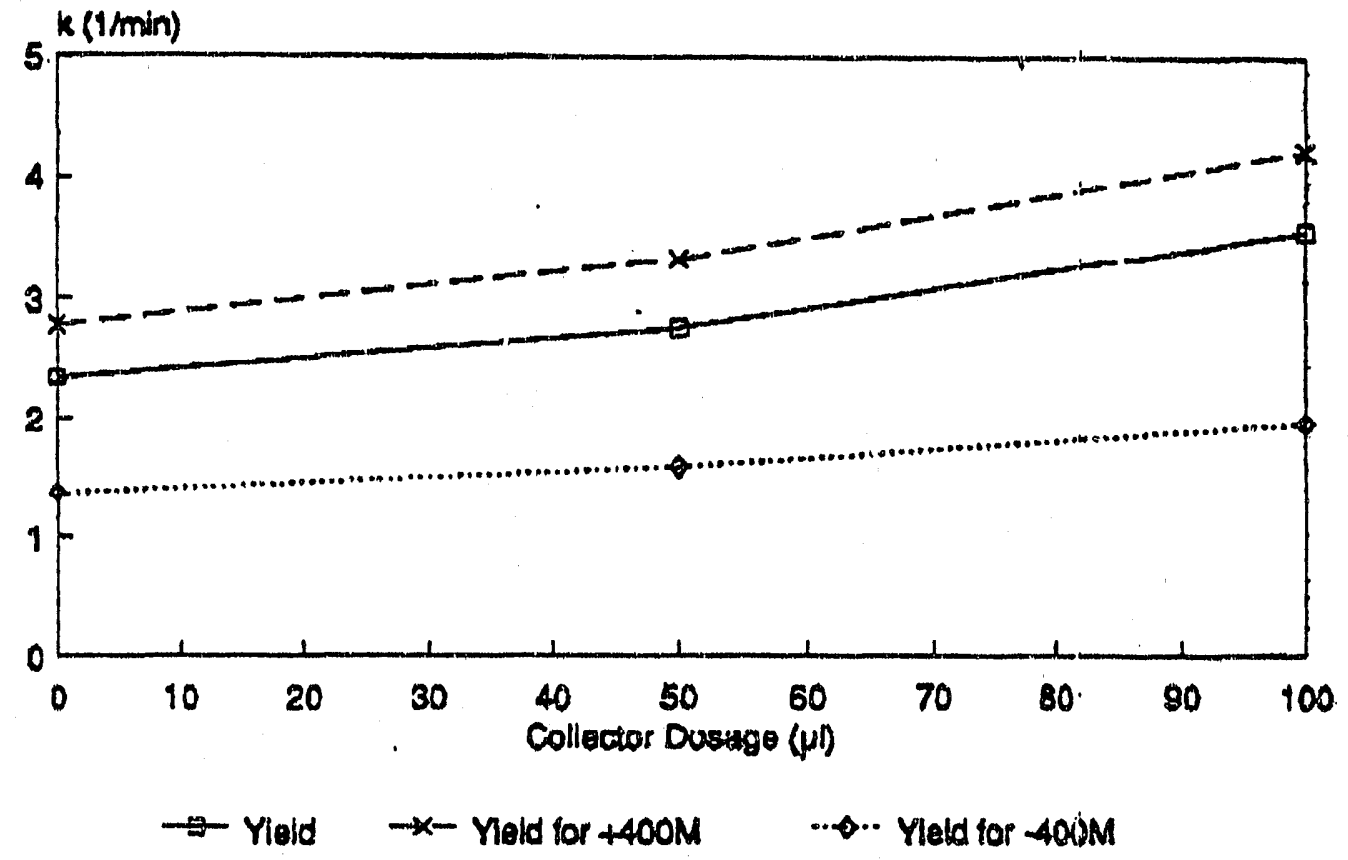

Figure 4. Flotation Rate Constant vs Collector Dosage (Upper Freoport)

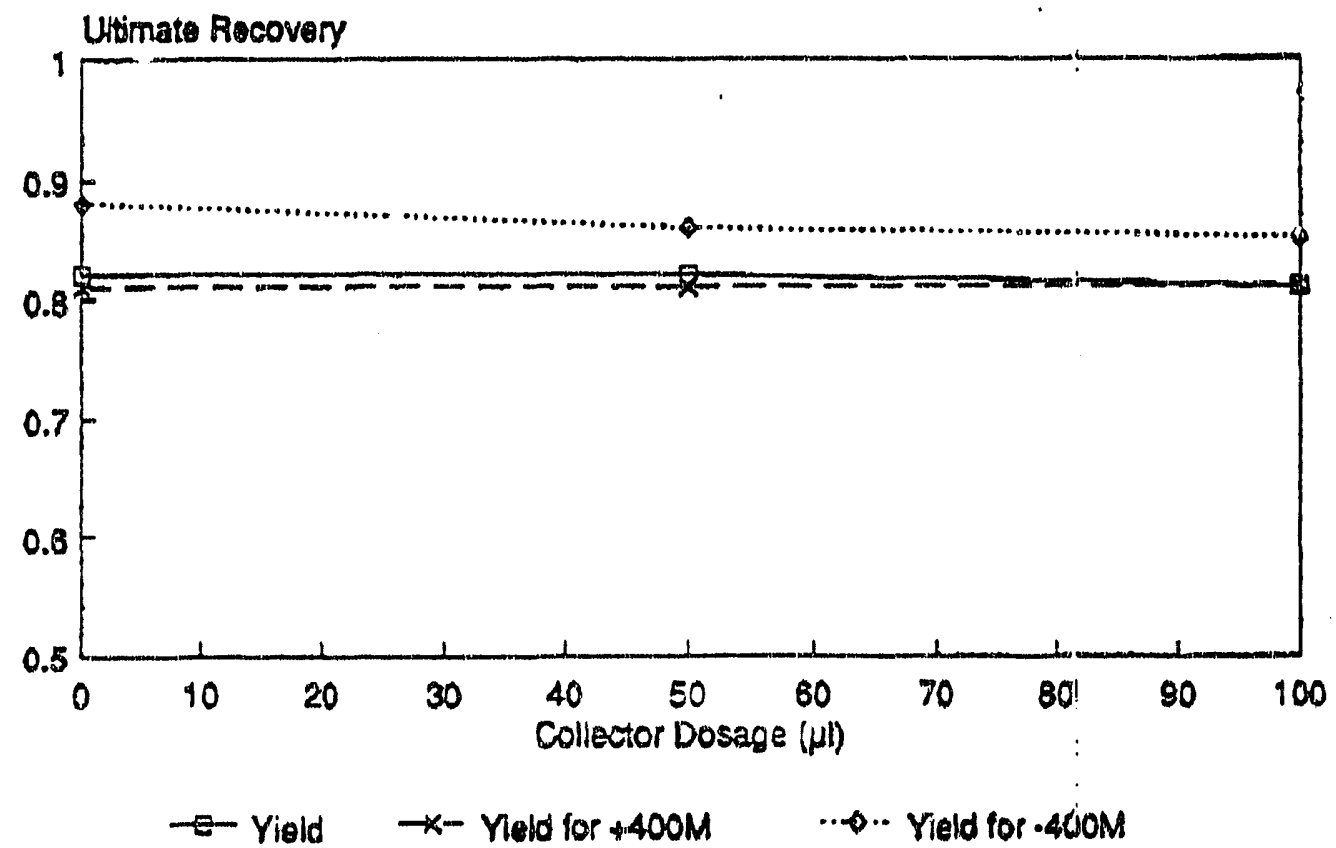

Figure 5. U1timate Recovery vs Collector Dosage (Upper Freeport) 


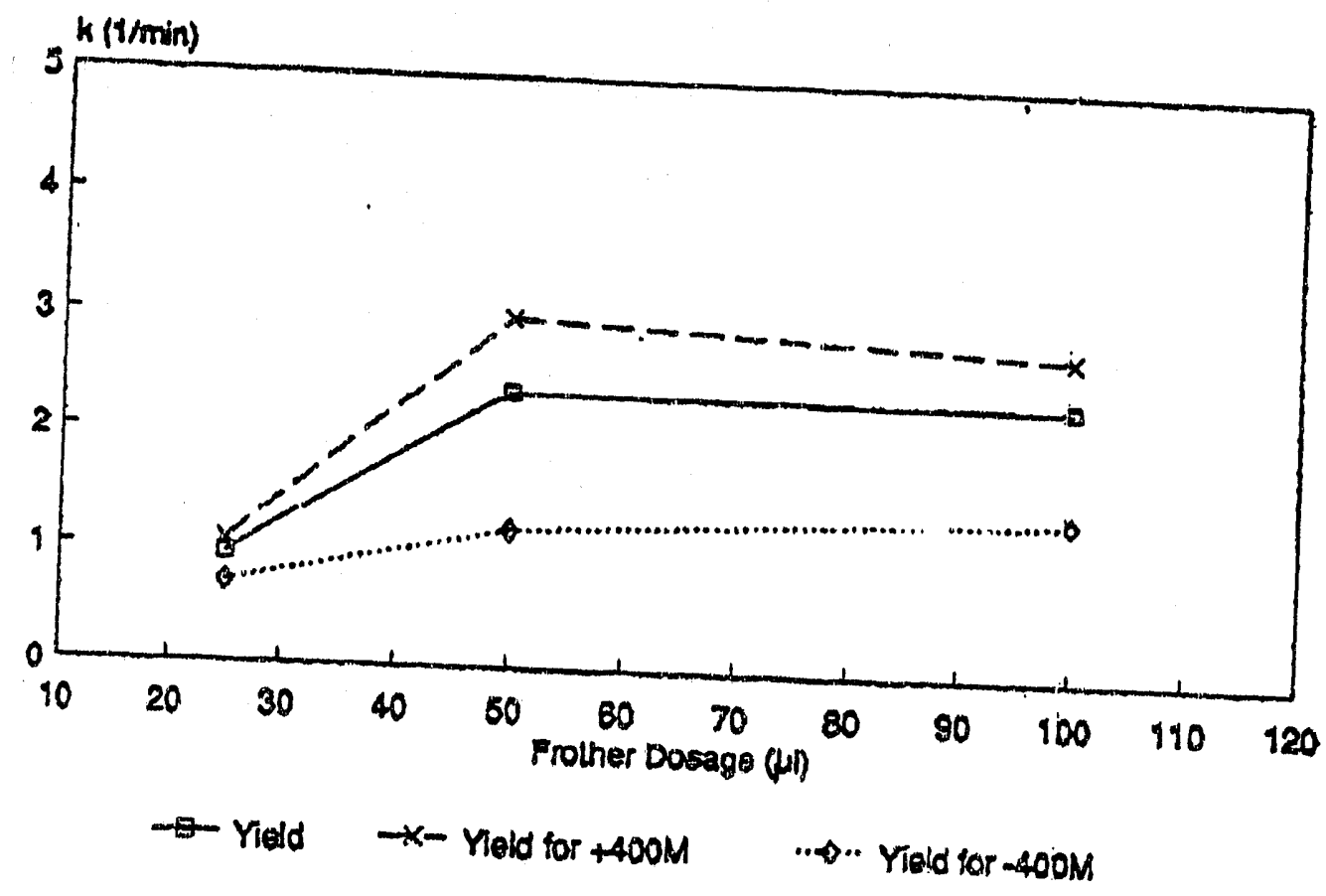

Figure 6. Flotation Rate Constant vs Frother Dosage (Upper Freeport)

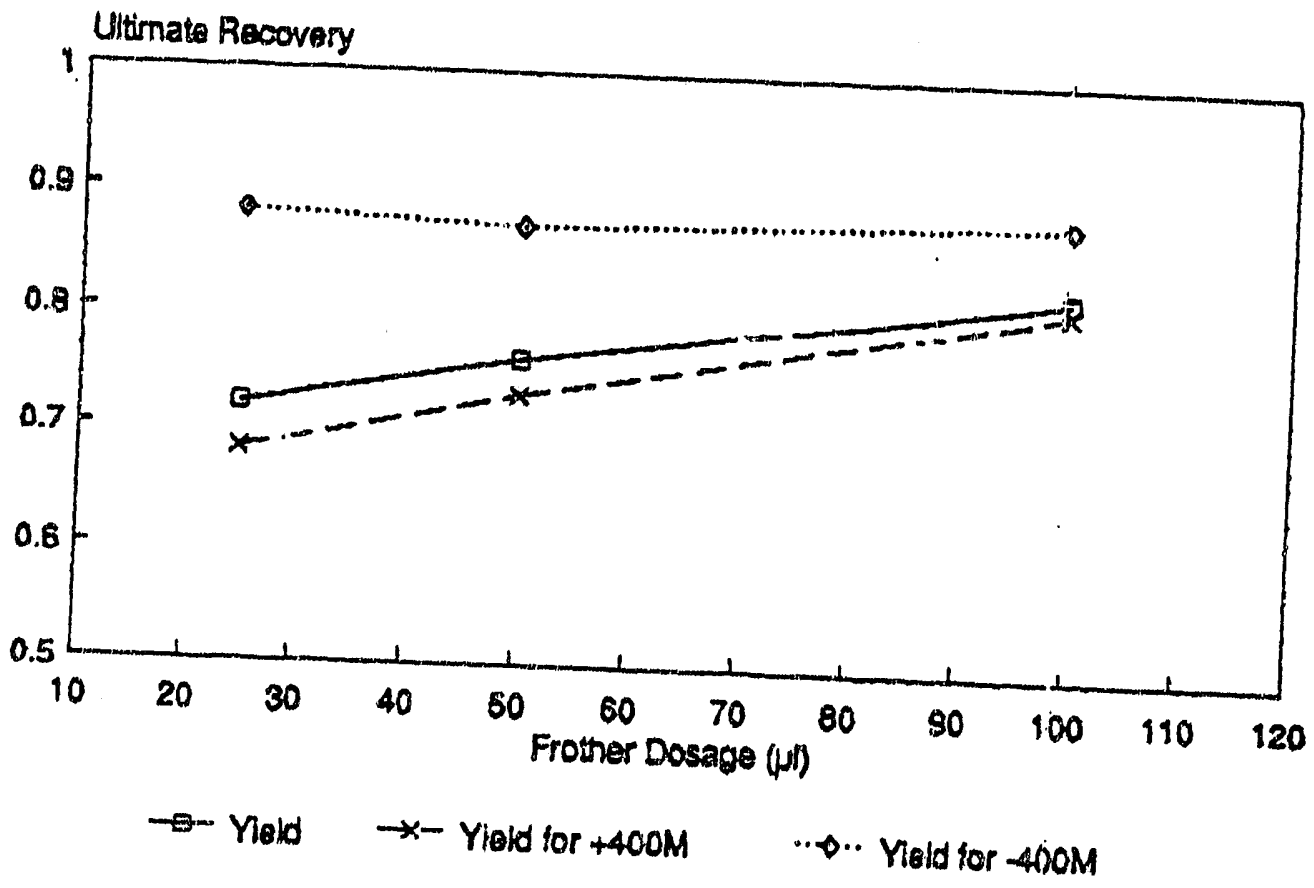

Figure 7. Uitimate Recovery rs Frother Dosage (Upper Freeport) 


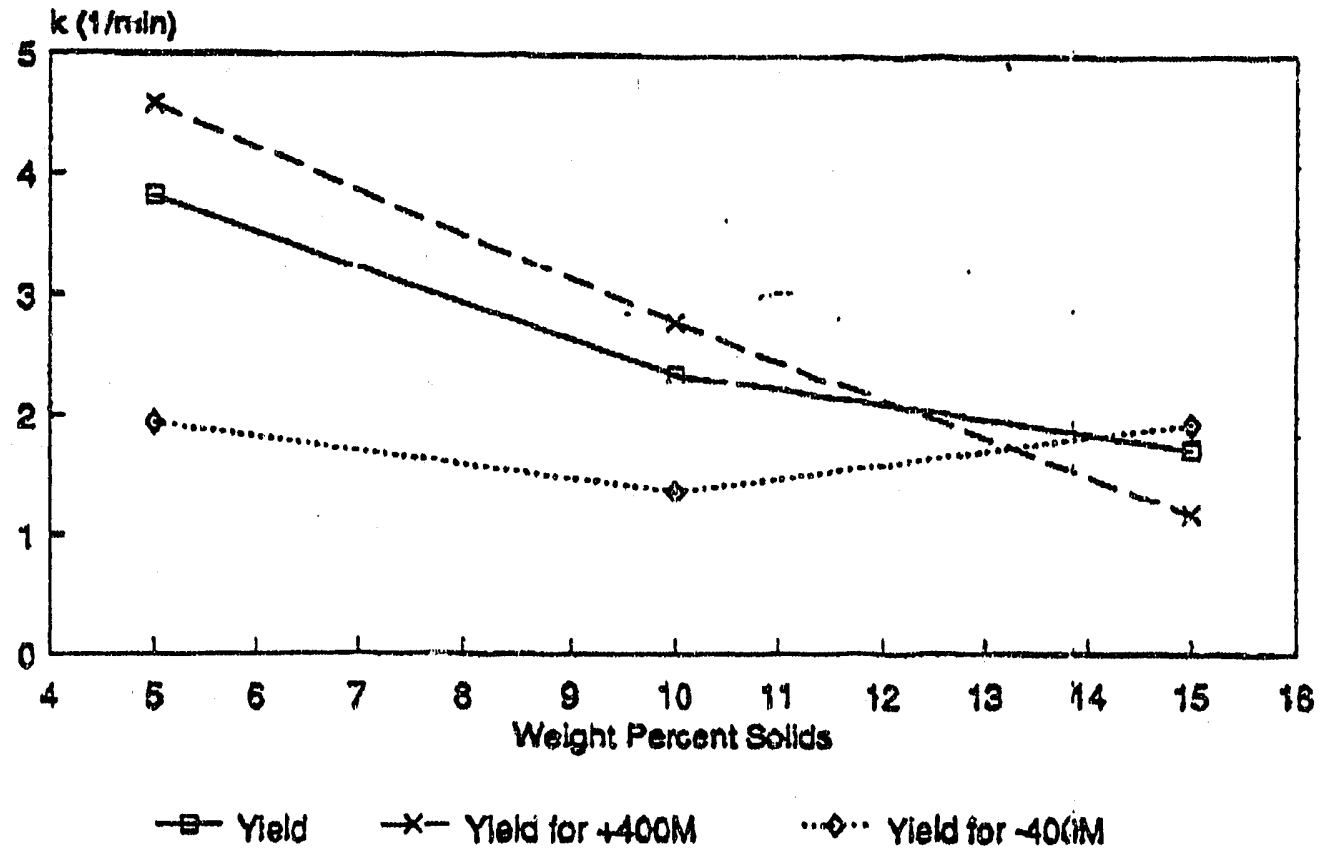

Figure 8. Flotation Rate Constant vs Percent Solids (Upper Freepert)

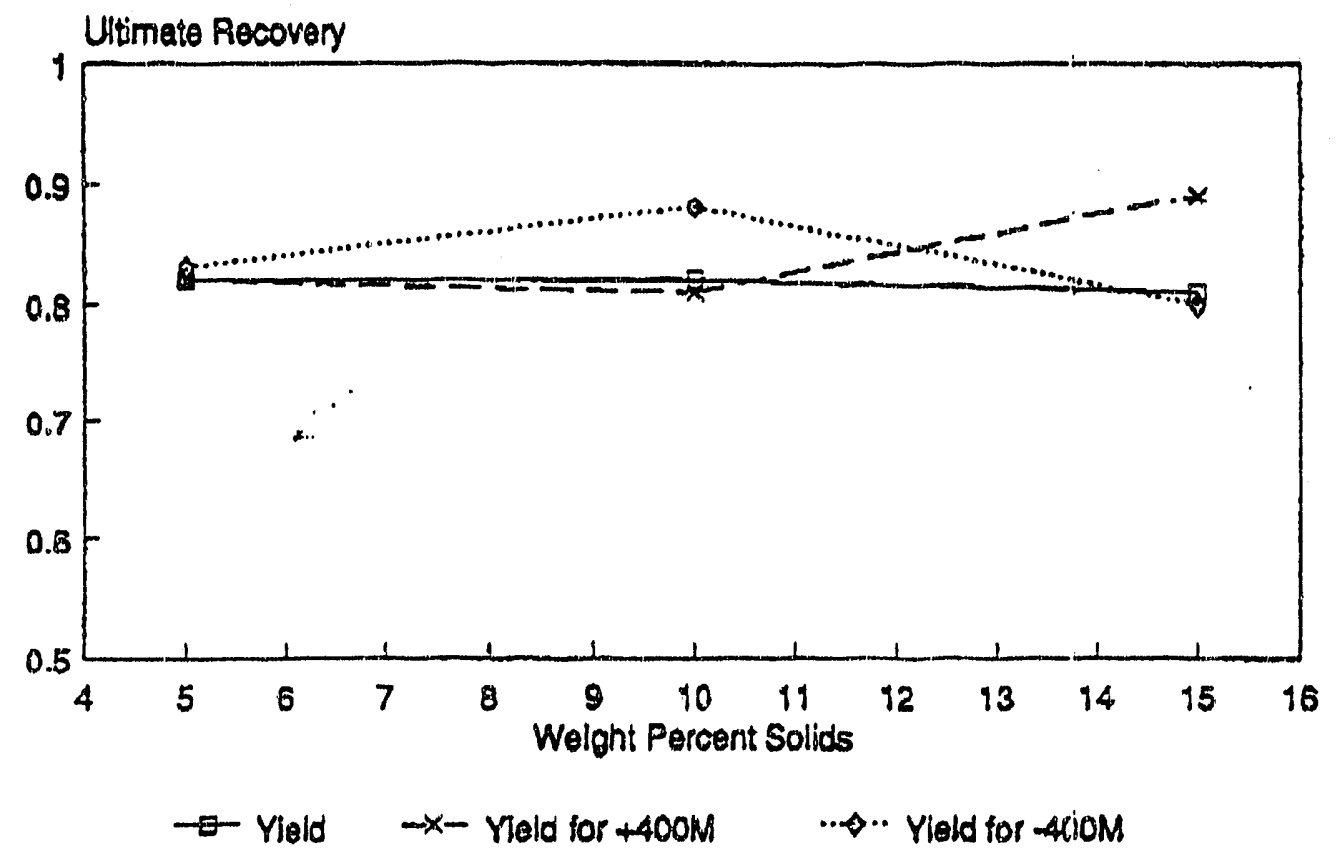

Figure 5. Uitimate Recovery vs Percent Solids (Upper Freepe 't) 


\subsection{QUARTER NO. 11 - MORK PLAN}

- In Task 2, complete models, complete model documentation, complate sesting and validation.

- Continue Tasks 3 and 4.

- In Task 5 complete Upper Freeport seam testing. Continue Pittsburgh seam testing. Begin Illinois Mo. 6 seam testing.

Conduct data reduction on Task 6 results for final model rate equation selection. 

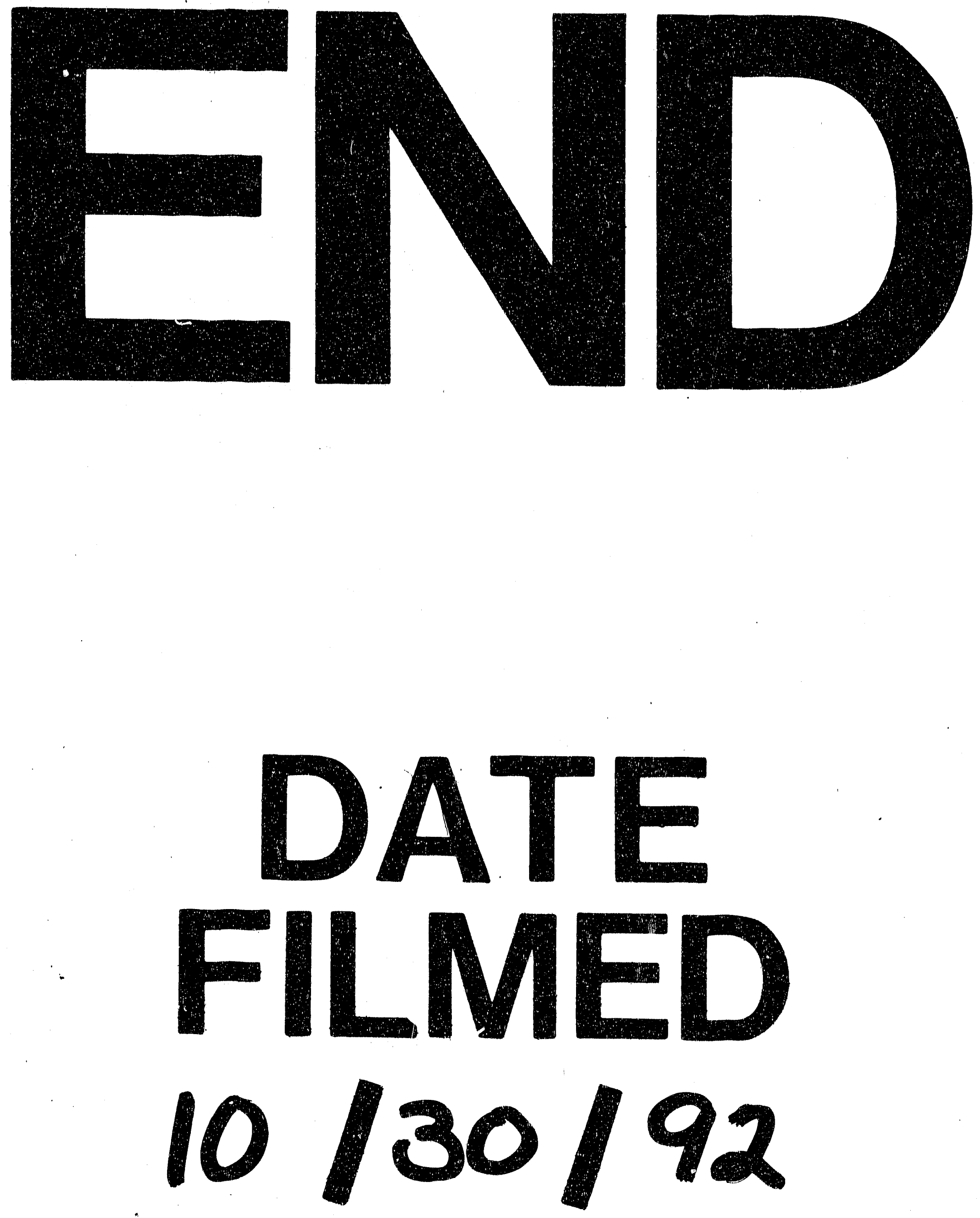
